Original Article

\title{
Densification mechanism of porous alumina plugs by molten steel with different oxygen levels
}

\author{
Liugang Chen ${ }^{\mathrm{a}, *}$, Annelies Malfliet ${ }^{\mathrm{a}}$, Lichun Zheng ${ }^{\mathrm{b}}$, Peter Tom Jones ${ }^{\mathrm{a}}$, Bart Blanpain ${ }^{\mathrm{a}}$, \\ Muxing Guo
}

${ }^{\text {a }}$ KU Leuven, Department of Materials Engineering, Arenberg Kasteelpark 44, Leuven, 3001, Belgium

${ }^{\mathrm{b}}$ Tohoku University, Institute of Multidisciplinary Research for Advanced Materials, Sendai, 980, Japan

\section{A R T I C L E I N F O}

\section{Keywords:}

Refractory

Porous alumina

Hydrogen probe measurements

Steel

Densification

\begin{abstract}
A B S T R A C T
To investigate the densification of porous alumina plugs, hydrogen measurements, using the Hydris probe system, were performed in molten steel with different oxygen levels at around $1600{ }^{\circ} \mathrm{C}$. The oxygen contents in molten steel were controlled by Al and Fe-Si alloy additions to 664, 296, 92, 51 and 2.5 ppm, respectively. High oxygen levels ( $>=92 \mathrm{ppm}$ ) in molten steel were found to favor the infiltration of steel into porous alumina plug. The infiltrating steel interacts with $\mathrm{SiO}_{2}$-containing phases and $\mathrm{Al}_{2} \mathrm{O}_{3}$ inside the plug, forming liquid $\mathrm{FeO}_{\mathrm{n}}$ $\mathrm{Al}_{2} \mathrm{O}_{3}-\mathrm{SiO}_{2}$ slag and $\mathrm{FeAl}_{2} \mathrm{O}_{4}$ (hercynite). These newly formed phases, along with the infiltrating steel fill the porous structure of the alumina plugs. As a result, severe densification was observed inside the alumina plugs in contact with molten steel containing high oxygen levels. In comparison, no densification occurred in the plugs contacting with the steel having low oxygen contents of 51 and $2.5 \mathrm{ppm}$.
\end{abstract}

\section{Introduction}

Porous alumina ceramic has been widely used in primary steelmaking (EAF and Converter shop) and ladle metallurgy (RH and Tundish practice) as ceramic bells for hydrogen measurements (Hydris probe system) [1-3], ceramic filters [4,5] and purging plugs [6,7], owing to its low cost and the high melting point of $\mathrm{Al}_{2} \mathrm{O}_{3}$. However, a drawback of using porous alumina ceramics is their vulnerability to steel with high oxygen levels. For example, using the Hydris system (hydrogen probe), the hydrogen content of liquid steel is measured by means of determining the hydrogen concentration in a nitrogen carrier gas. The carrier gas is injected into the steel through the probe to absorb the hydrogen until equilibrium is attained between gas and steel, and is then recollected by a porous alumina plug and then analyzed in the pneumatic unit (Fig. 1). However, it has been observed that the alumina plug in such measurement suffers from different levels of densification, thereby affecting the recirculation of carrier gas and thus the accuracy of the measured hydrogen concentration. Therefore, knowledge of the densification mechanism of alumina plugs is indispensable in improving the lifetime of porous alumina ceramic and controlling the steel quality and operation safety during ironmaking and steelmaking processes.

Interactions between dense alumina and liquid steel have been reported in a number of studies [8-12]. It is reported that $\mathrm{Al}_{2} \mathrm{O}_{3}$ is unwetted by molten steel. However, $\mathrm{Al}_{2} \mathrm{O}_{3}$ will be wetted by molten steel once the steel is contaminated with oxygen and this wettability is favored by increasing the oxygen level in the steel [8-12]. $\mathrm{FeAl}_{2} \mathrm{O}_{4}$ hercynite can then be generated at the $\mathrm{Al}_{2} \mathrm{O}_{3}$ /steel interface by the $\mathrm{Al}_{2} \mathrm{O}_{3} /$ steel interaction [8-12]. It can be therefore inferred from these results that the densification of porous alumina plug may be caused by the wetting of molten steel with oxygen, which results in the infiltration of molten steel. However, until now there are no experimental studies available confirming this conjecture.

In this work, the densifying behavior of porous alumina ceramic in molten steel is investigated. The tests were carried out by hydrogen probe measurements in molten steel in an induction furnace. To examine the influence of oxygen level on the densification behavior, the oxygen concentration in the steel was controlled by adding different amounts of Fe-Si alloy and Al during the tests. The densification mechanisms are studied by the characterization of the microstructure of the porous alumina ceramics after tests, using scanning electron microscope (SEM) equipped with energy dispersive spectroscopy (EDS).

\section{Experimental}

\subsection{Experiment set-up and procedure}

Hydrogen measurements (Hydris probe system) were conducted in

\footnotetext{
* Corresponding author at: KU Leuven, Department of Materials Engineeering, Arenberg Kasteelpark 44, Leuven, 3001, Belgium.

E-mail address: liugang.chen@mtm.kuleuven.be (L. Chen).
} 


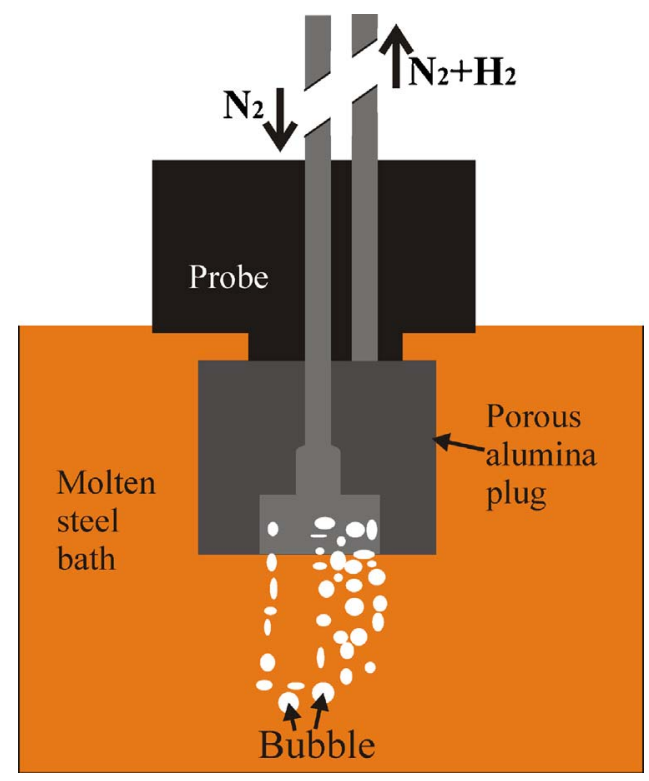

Fig. 1. Schematic of the porous alumina plug during hydrogen measurements (Hydris probe system).

an induction furnace (Inductotherm, Elphiac) at Electro-Nite (Houthalen, Belgium). Approximately $250 \mathrm{~kg}$ of steel was held in a refractory crucible, the inner lining of which consists mainly of $\mathrm{MgO}$, and melted at around $1600^{\circ} \mathrm{C}$ in the furnace. The schematic drawing of the probe for hydrogen measurement is shown in Fig. 1. A series of hydrogen probe measurements was performed by adding deoxidation agents (Fe-Si alloy and $\mathrm{Al}$ ) to the molten steel in order to reduce the oxygen content. The first measurement was performed with an initial oxygen level of $664 \mathrm{ppm}$ before the first killing. After each addition of Fe-Si alloy and $\mathrm{Al}$, oxygen in the molten steel was examined by an oxygen probe and a metal sample was taken for compositional analysis with spectroscopic spark emission. After the oxygen content was found to be stable, a new hydrogen probe measurement was performed. The measured oxygen contents and steel composition are listed in Table 1. Curves of hydrogen content and recollected carrier gas pressure were recorded and displayed on the screen of the processor. From these curves one can indirectly observe the densifying extent of the alumina plug during measurements (as discussed in Section 3.2.1). After measuring for around 20s or $60 \mathrm{~s}$, depending on the extent of densification, the probe was removed from the molten steel and quenched in a stream of nitrogen.

\subsection{Sample analysis technique}

After measurements, alumina plugs were recovered for microstructural investigation. To evaluate the interaction between the alumina plug and molten steel, specimens were extracted at the upper part along the vertical direction from each recovered plug as demonstrated in Fig. 2. The specimens were embedded in a low viscosity resin

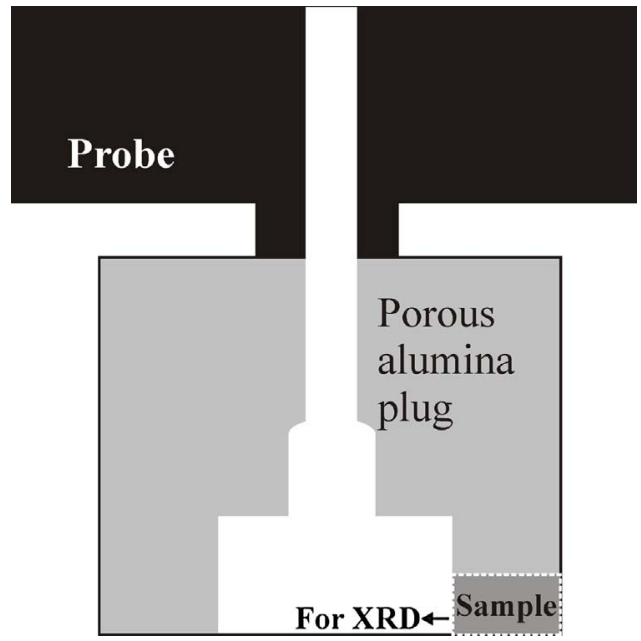

Fig. 2. Sample extraction scheme for SEM and XRD investigation.

(Epofix) by vacuum impregnation, ground with diamond plates and polished with diamond paste. The polished specimens were coated with a layer of carbon and characterized with a scanning electron microscope (SEM, XL-30 FEG, FEI), equipped with an energy dispersive spectroscope (EDS, EDAX) with an ultra-thin window. The plug surface contacting with molten steel after testing (as shown in Fig. 2) was slightly ground to keep it flat and characterized by X-ray powder diffraction (XRD, D2, Bruker) to examine phase compositions at the steel/ plug interface.

\subsection{Thermodynamic calculations}

The thermodynamic software package FactSage 7.1 was used to support the analysis results [13]. Equilibrium calculations were performed with the equilibrium module EQUILIB, which is based on the minimization of the Gibbs free energy, and the FSstel, FT oxide and Fact PS databases. The following possible solution phases were chosen in the calculations: (1) FSstel-LIQU, (2) FToxide-SLAGA (molten oxide phase); (3) FT oxide-MeO_A (oxide solid solution); (4) FT oxide-SPINA (spinel solid solution); (5) FToxide-Mull (mullite solid solution); (6) FT oxideCORU (corundum), and (7) FACT PS (gas phase). The steel/refractory interactions were modeled at $1600^{\circ} \mathrm{C}$ by addition of one gram or two grams (x g) refractory components of $\mathrm{Al}_{2} \mathrm{O}_{3}$, mullite $\left(71.8 \mathrm{wt} \% \mathrm{Al}_{2} \mathrm{O}_{3}\right.$ and $28.2 \mathrm{wt} \% \mathrm{SiO}_{2}$ ) or a $\mathrm{SiO}_{2}-\mathrm{Al}_{2} \mathrm{O}_{3}$ mixture $\left(50 \mathrm{wt} \% \mathrm{Al}_{2} \mathrm{O}_{3}\right.$ and $50 \mathrm{wt} \%$ $\mathrm{SiO}_{2}$ ) to the steel [(100-x-y-z) g)] without or with $0.47 \mathrm{wt} \% \mathrm{Si}(\mathrm{y} \mathrm{g})$. $\mathrm{SiO}_{2}-\mathrm{Al}_{2} \mathrm{O}_{3}$ mixture was used to mimic the $\mathrm{SiO}_{2}$-rich phases in the plug. The oxygen level in the molten steel ranges from 0 to $700 \mathrm{ppm}(\mathrm{z} \mathrm{g})$ in the calculation.

\section{Results}

\subsection{As-delivered porous alumina plug}

Fig. 3 presents the microstructure of the as-delivered alumina plug.

Table 1

Experimental parameters for the hydrogen probe measurements.

\begin{tabular}{|c|c|c|c|c|c|c|c|c|}
\hline \multirow[t]{2}{*}{ Exp. no. } & \multirow[t]{2}{*}{ Temperature $\left({ }^{\circ} \mathrm{C}\right)$} & \multirow[t]{2}{*}{$\underline{\mathrm{O}}(\mathrm{ppm})$} & \multicolumn{6}{|c|}{ Chemical composition of the steel (wt $\%$ ) } \\
\hline & & & $\mathrm{C}$ & $\mathrm{Si}$ & $\mathrm{Ni}$ & $\mathrm{Cu}$ & $\mathrm{Fe}$ & Others \\
\hline 1 & 1608 & 664 & 0.03 & 0.01 & 0.23 & 0.45 & 98.8 & 0.48 \\
\hline 2 & 1626 & 296 & 0.03 & 0.09 & 0.23 & 0.45 & 98.7 & 0.50 \\
\hline 3 & 1627 & 92 & 0.03 & 0.21 & 0.23 & 0.45 & 98.5 & 0.58 \\
\hline 4 & 1616 & 51 & 0.03 & 0.31 & 0.22 & 0.45 & 98.3 & 0.49 \\
\hline 5 & 1627 & 2.5 & 0.02 & 0.47 & 0.23 & 0.45 & 98.4 & 0.43 \\
\hline
\end{tabular}



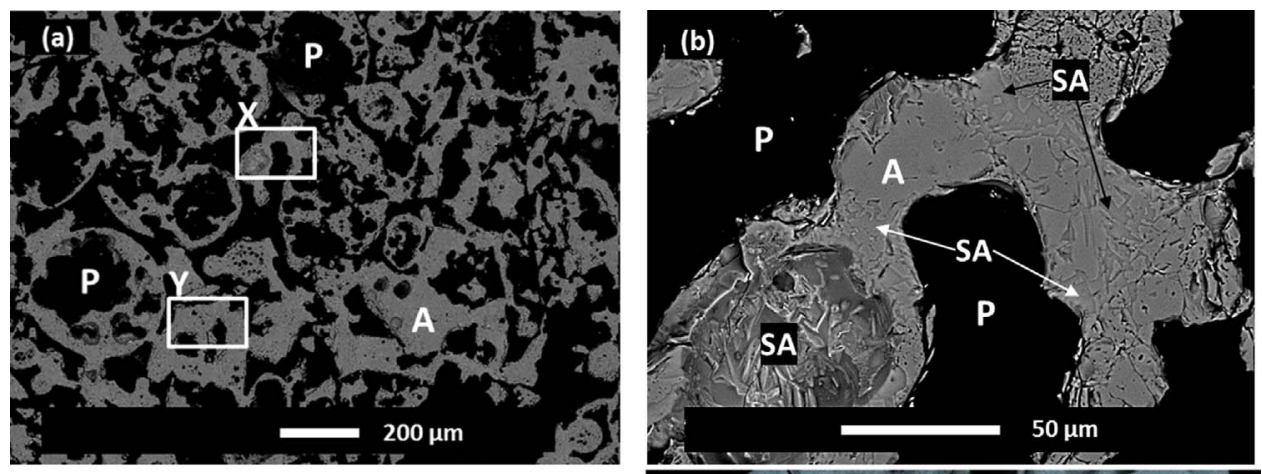

Fig. 3. (a) overview of the as-delivered alumina plug, (b) and (c) detailed images of selected areas $\mathrm{X}$ and $\mathrm{Y}$, respectively, and (d) $\mathrm{Al}$ and (e) Si EDS elemental mapping of the select area $\mathrm{Y} ; \mathrm{A}=\mathrm{Al}_{2} \mathrm{O}_{3}$ phase; $\mathrm{SA}=\mathrm{SiO}_{2}$-containing phase; $\mathrm{P}=$ pores.
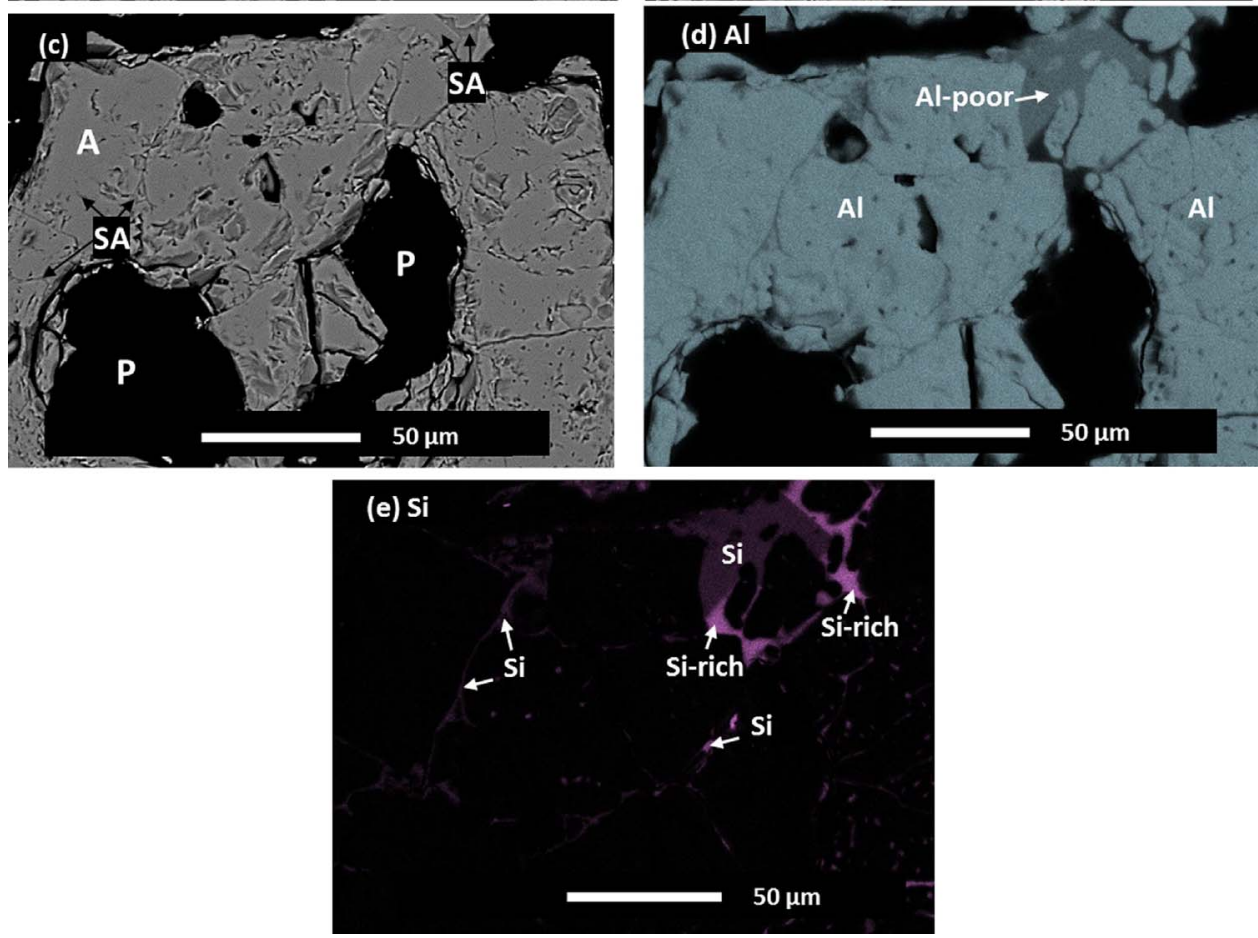

A very extensive open pore network is observed, since the plug is porous. Solid phases, mainly consisting of pure $\mathrm{Al}_{2} \mathrm{O}_{3}$, form a framework in the plug. Besides the pure alumina phase, $\mathrm{SiO}_{2}$-containing phases ('SA' in Fig. 3b and c) are found mainly located at the grain boundaries of $\mathrm{Al}_{2} \mathrm{O}_{3}$ phases as impurities. A mixture of Al-poor and $\mathrm{SiO}_{2}$-rich phases, as shown in Fig. 3c-e, is observed. Compositional analyses by EDS that the $\mathrm{Al}_{2} \mathrm{O}_{3}$-poor phase would be crystal mullite $\left(3 \mathrm{Al}_{2} \mathrm{O}_{3} \cdot 2 \mathrm{SiO}_{2}\right) \quad$ containing $65.4 \pm 1.5 \mathrm{~mol} \% \quad \mathrm{Al}_{2} \mathrm{O}_{3} \quad$ and $34.5 \pm 1.4 \mathrm{~mol} \% \mathrm{SiO}_{2}$, and the $\mathrm{SiO}_{2}$-rich phase would be an amorphous phases consisting of $28.3 \pm 14.6 \mathrm{~mol} \% \mathrm{Al}_{2} \mathrm{O}_{3}, 68.9 \pm 13.5 \mathrm{~mol}$ $\% \mathrm{SiO}_{2}, 2.5 \pm 1.0 \mathrm{~mol} \% \mathrm{Na}_{2} \mathrm{O}$, and $0.3 \pm 0.2 \mathrm{~mol} \% \mathrm{CaO}$.

\subsection{Macroscopical observation of the densification behavior}

\subsubsection{Measured curves of recollected gas pressure and hydrogen content}

Fig. 4 shows the measured curves of hydrogen content and recollected carrier gas pressure. In Fig. 4, the $\mathrm{O}$ level ( $\mathrm{O}$ in the figure), which decreases from $664 \mathrm{ppm}$ to $2.5 \mathrm{ppm}$, is the main parameter. As demonstrated in Fig. 4a and b, the pressure of the carrier gas (recirculated in the system) abruptly dropped to an extremely low value of below $200 \mathrm{hPa}$ and the hydrogen contents sharply increased after measuring for between $10 \mathrm{~s}$ and $20 \mathrm{~s}$. These observations indicate that serious densification of alumina plugs occurred in Test 1 and Test 2, in which the steel contained $664 \mathrm{ppm}$ and $296 \mathrm{ppm}$ oxygen, respectively. When the oxygen content was lowered to $92 \mathrm{ppm}$ in Test 3 (Fig. 4c), the decrease in the carrier gas pressure and increase of the hydrogen content during the measurement was moderated, suggesting that the extent of densification was reduced compared with Test 1 and Test 2. However, the amount of carrier gas, which was recollected by the alumina plug, was still insufficient for the measurement. With further decreasing the oxygen level in the molten steel to $51 \mathrm{ppm}$ and $2.5 \mathrm{ppm}$ in Test 4 (Fig. 4d) and Test 5 (Fig. 4e), respectively, the hydrogen concentrations in the carrier gas gradually increased to a maximum value of $7.0 \mathrm{ppm}$ after measuring for $50 \mathrm{~s}$ and stabilized thereafter. Meanwhile, the pressure of carrier gas decreased slowly and kept constant after measuring for $50 \mathrm{~s}$. These characteristics of the measured curves suggest that there was no alumina plug densification in Test 4 and Test 5 . It is obvious from the measured curves that the densification of alumina plugs is related to the oxygen level in the molten steel.

\subsubsection{Appearance of the tested alumina plug}

The appearances of recovered alumina plugs after completion of the tests are shown in Fig. 5. The amount of steel adhered on the outer surface of alumina plug is closely correlated with the oxygen content in the molten steel. A substantial quantity of attached steel was observed for Test 1 and 2 with oxygen contents of 664 and $296 \mathrm{ppm}$, respectively. With decreasing the oxygen contents to $92 \mathrm{ppm}$ (Test 3), $51 \mathrm{ppm}$ (Test 4) and $2.5 \mathrm{ppm}$ (Test 5), the amount of attached steel continuously decreased. These observations indicate that higher oxygen levels in the molten steel favoured the sticking of steel on the alumina plug surface. 


\section{(a) Test $1 \underline{0}=664 \mathrm{ppm}$ densified}

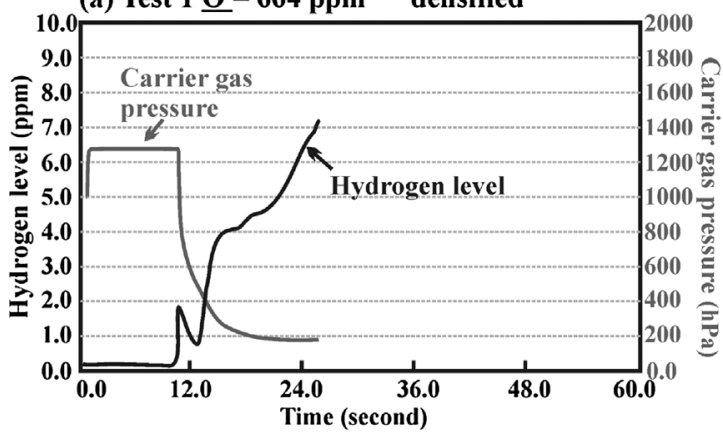

(d) Test $4 \underline{O}=51 \mathrm{ppm}$ successful

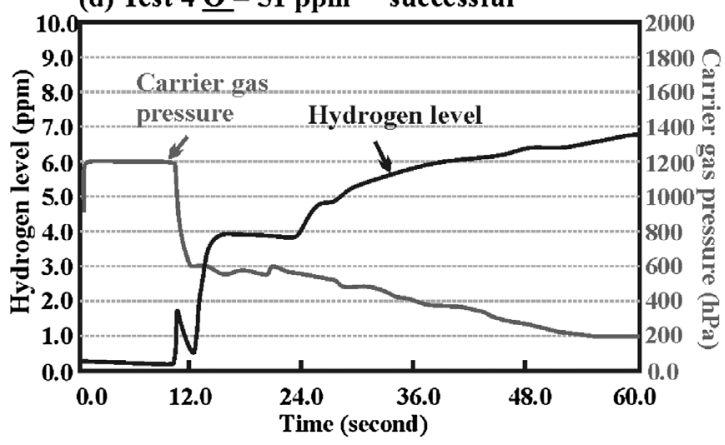

(e) Test $5 \underline{0}=2.5 \mathrm{ppm} \quad$ successful

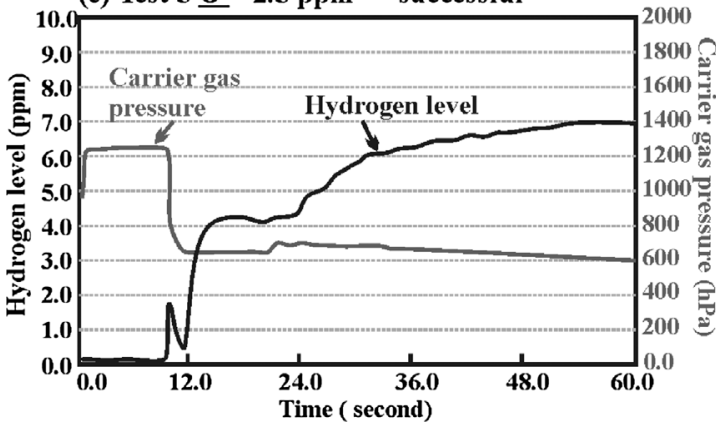

(b) Test $2 \underline{O}=296 \mathrm{ppm} \quad$ densified

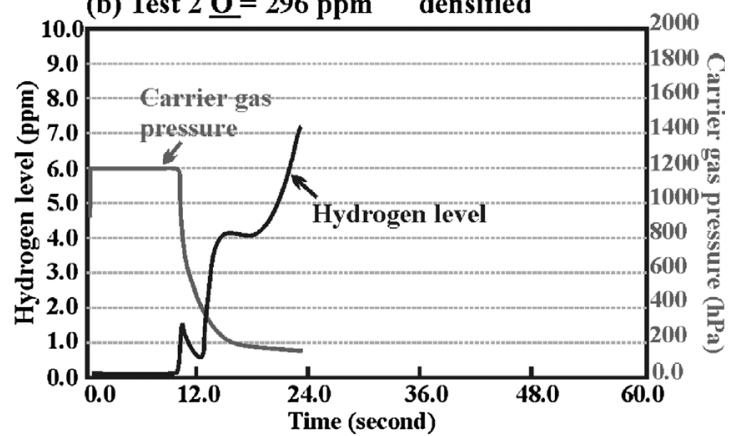

(c) Test $3 \underline{O}=92 \mathrm{ppm}$

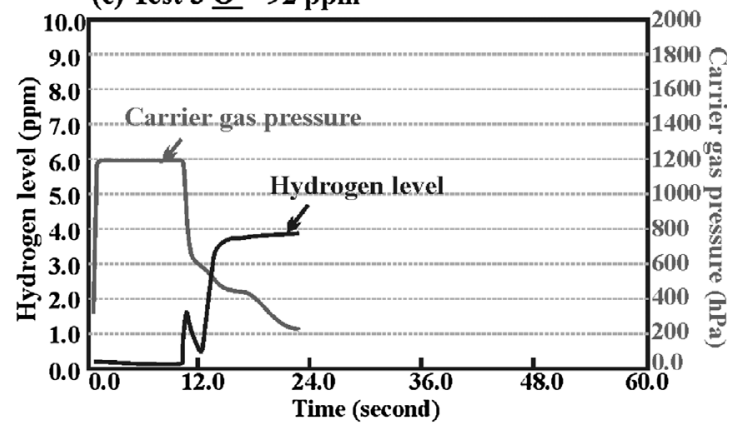

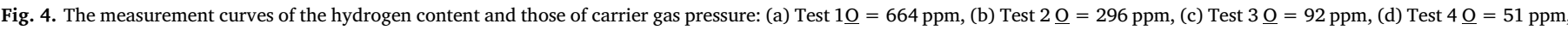
and (e) Test $5=02.5 \mathrm{ppm}$.

This is consistent with the results shown in Fig. 4, where the higher oxygen level in the steel brought about a more severe densification of the alumina plug. To understand the influence of oxygen content in liquid steel on the densification of alumina plugs, the microstructure of tested alumina plugs was analyzed and is presented in the next section.

\subsection{Microstructural features of tested alumina plugs}

Phase compositions at the steel/plug interface from Test 2 (with 296 ppm oxygen) are shown in Fig. 6. $\alpha-\mathrm{Al}_{2} \mathrm{O}_{3}$, metallic iron, $\mathrm{Fe}_{2} \mathrm{SiO}_{4}$ fayalite, $\mathrm{FeAl}_{2} \mathrm{O}_{4}$ hercynite, $\mathrm{Fe}_{2.932} \mathrm{O}_{4}$ magnetite and $\mathrm{Fe}_{2} \mathrm{O}_{3}$ hematite are observed at the plug surface contacting with the molten steel. $\mathrm{FeAl}_{2} \mathrm{O}_{4}$

\section{$\underline{\mathbf{O}}$ level (ppm):}

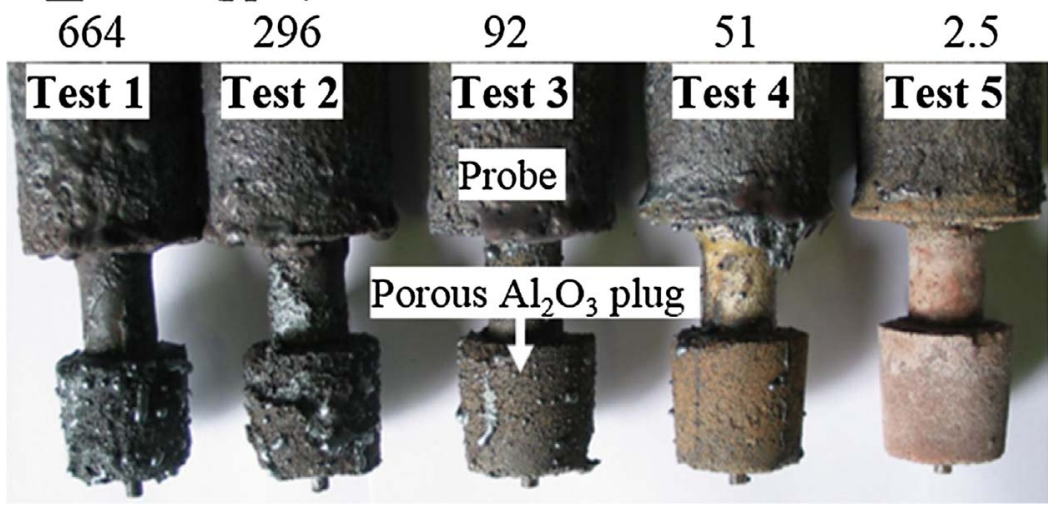

Fig. 5. Appearance of the alumina plugs after testing in the molten steel with distinct oxygen levels from Test 1 to Test 5 . 


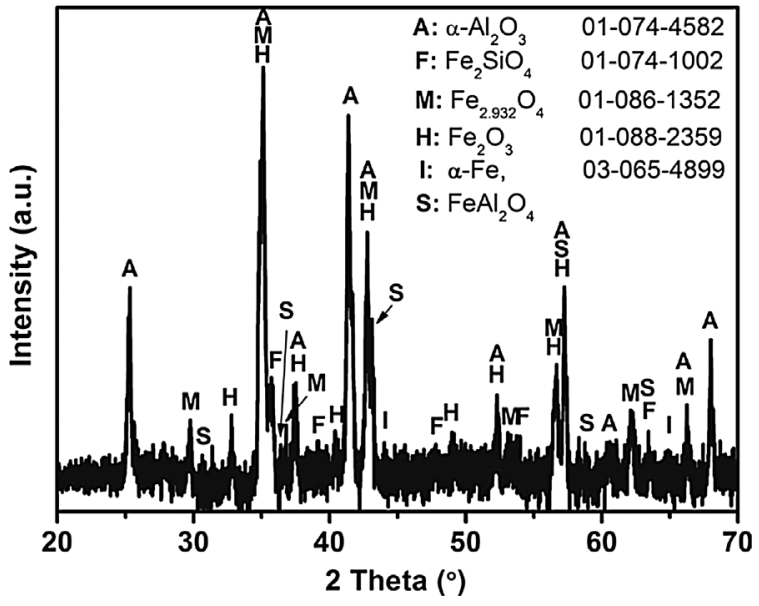

Fig. 6. Phase composition at liquid steel/plug interface of the sample from Test 2 . The $\mathrm{FeAl}_{2} \mathrm{O}_{4}$ hercynite (spinel) is identified by comparing the peak positions in this particular work with those in Ref. [14,15].

hercynite $(2 \theta=36.4)$ and $\mathrm{Fe}_{2} \mathrm{SiO}_{4}$ fayalite are most likely generated from the interactions between molten steel and plug. $\alpha-\mathrm{Al}_{2} \mathrm{O}_{3}$ and metallic iron are from the plug and molten steel, respectively. $\mathrm{Fe}_{2.932} \mathrm{O}_{4}$ magnetite and $\mathrm{Fe}_{2} \mathrm{O}_{3}$ hematite are possibly formed by the oxidation of attached steel after probe testing.

An overview of the microstructure of the recovered alumina plug from Test 1 (with $664 \mathrm{ppm}$ oxygen) at the molten steel/ $\mathrm{Al}_{2} \mathrm{O}_{3}$ plug interface is shown in Fig. 7a. A completely different microstructure as compared with the virgin sample (Fig. 3 ) is observed. At the hot face of the alumina plug an interaction layer with a thickness of over $3 \mathrm{~mm}$ was seen. This layer consists of a large amount of infiltrating steel, unreacted alumina particles, and newly-formed $\mathrm{FeO}_{\mathrm{n}}-\mathrm{Al}_{2} \mathrm{O}_{3}-\mathrm{SiO}_{2}$ liquid slag, hercynite $\left(\mathrm{FeAl}_{2} \mathrm{O}_{4}\right)$ and fayalite $\left(\mathrm{Fe}_{2} \mathrm{SiO}_{4}\right)$, as indicated by XRD
(Fig. 6) and EDS (Table 2) measurements. In the interaction layer, $\mathrm{FeAl}_{2} \mathrm{O}_{4}$ is observed in the $\mathrm{FeO}_{\mathrm{n}}-\mathrm{Al}_{2} \mathrm{O}_{3}-\mathrm{SiO}_{2}$ slag matrix which surrounds undissolved alumina grains. The original open pore network in the plug was densified with the infiltrating steel and newly-formed phases from the interactions between the steel and the plug (Fig. 7c, d).

\subsection{Influence of oxygen content on the steel infiltration}

Fig. 8 shows the changes in the amounts of the infiltrating steel and the newly-formed phases (hercynite, fayalite and $\mathrm{FeO}_{\mathrm{n}}-\mathrm{Al}_{2} \mathrm{O}_{3}-\mathrm{SiO}_{2}$ liquid slag) in the interaction layer at the surface of the samples contacting with molten steel as a function of oxygen content in the molten steel bath. The thickness of the infiltrated layer continuously decreases from $>3 \mathrm{~mm}$ in Test 1 with an oxygen level of $664 \mathrm{ppm}$ (Fig. 7a), to $1.6 \mathrm{~mm}$ in Test 3 (Fig. 8a) and $200 \mu \mathrm{m}$ in Test 5 (Fig. 8b) with oxygen contents of $92 \mathrm{ppm}$ and $2.5 \mathrm{ppm}$, respectively. It is evident that the amount of infiltrating steel decreases with lowering the oxygen content in the steel bath. Correspondingly, the amount of the newly formed hercynite, fayalite and $\mathrm{FeO}_{\mathrm{n}}-\mathrm{Al}_{2} \mathrm{O}_{3}-\mathrm{SiO}_{2}$ liquid slag at the surface of alumina plugs is also found to be decreased with reducing the oxygen content in the steel bath. When the steel was killed to $2.5 \mathrm{ppm}$ oxygen (Test 5, Fig. 8b), only a very small amount of steel was found in the pores of $\mathrm{Al}_{2} \mathrm{O}_{3}$ plug at the steel/plug interface. Compared with the sample from Test 1 with an oxygen content of $664 \mathrm{ppm}$ (Fig. 7a), no distinct interaction layer was observed at the surface of the sample from Test 5 (Fig. 8b). This is compatible with the visual observations in Fig. 5 and with the hydrogen measurement results (Fig. 4).

\section{Discussion}

\subsection{Densification mechanism of porous alumina plugs}

Based on the aforementioned results, it can be summarized that the

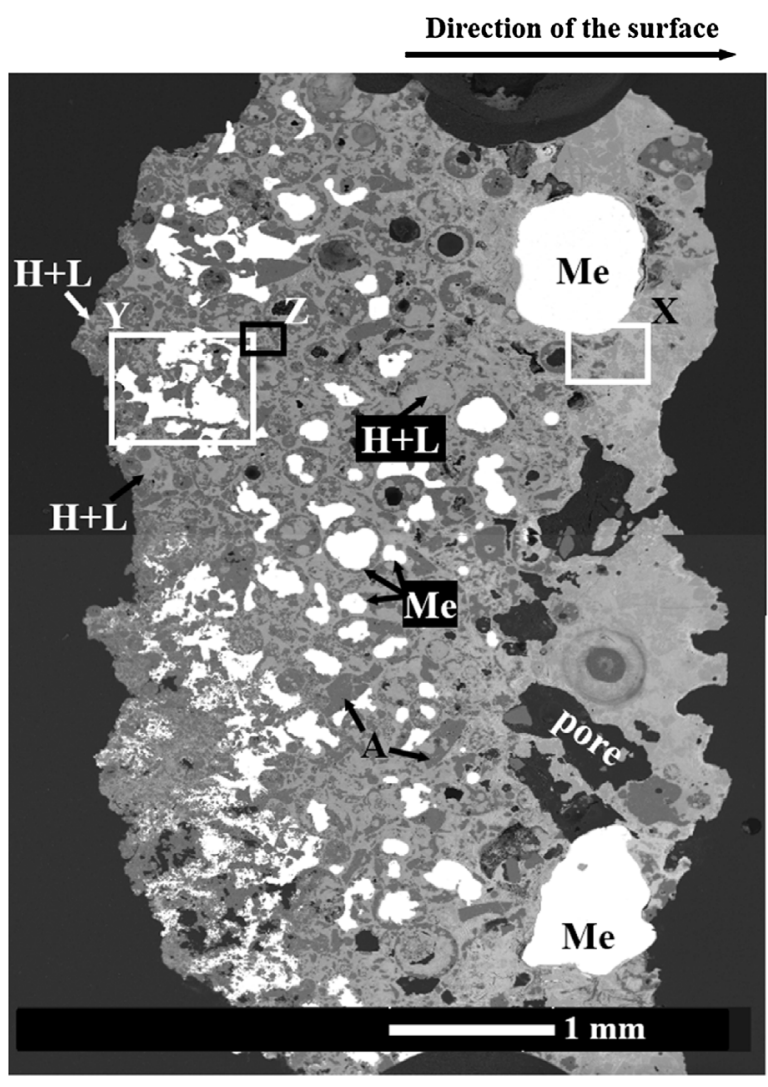

(a) Overview of the hot face

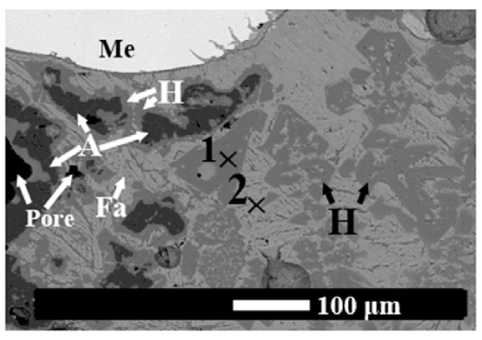

(b) BSE image from position $\mathrm{X}$ of (a)

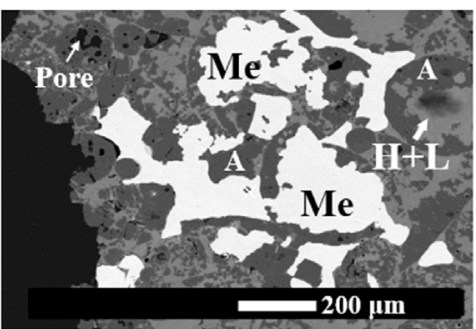

(c) BSE image from position $Y$ of (a)

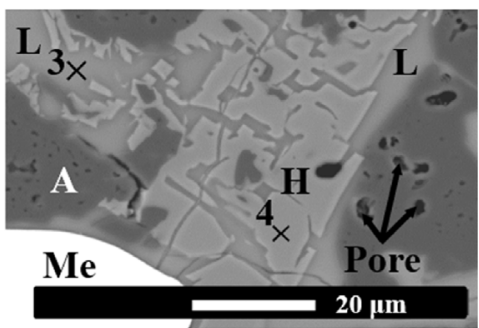

(d) BSE image from position $\mathrm{Z}$ of (a)
Fig. 7. Microstructure at liquid steel/ plug interface of the sample from Test 1: (a) overview of the interaction layer, and (b), (c) and (d) enlarged views of positions $\mathrm{X}, \mathrm{Y}$, and $\mathrm{Z}$ in (a), respectively: $\mathrm{Me}=$ metallic iron particle; $\mathrm{A}=\mathrm{Al}_{2} \mathrm{O}_{3} ; \mathrm{L}=\mathrm{FeO}_{\mathrm{n}}$ $\mathrm{Al}_{2} \mathrm{O}_{3}-\mathrm{SiO}_{2}$ liquid slag; $\mathrm{H}=\mathrm{FeAl}_{2} \mathrm{O}_{4}$ hercynite; $\mathrm{Fa}=$ $\mathrm{Fe}_{2} \mathrm{SiO}_{4}$ fayalite; $\times=$ analysis spots (the chemical compositions are listed in Table 2). 
Table 2

Chemical compositions of the selected points in the interaction layer in Fig. 6, as determined by SEM-EDS.

\begin{tabular}{|c|c|c|c|c|c|c|c|}
\hline Spot No. & Phase & $\begin{array}{l}\mathrm{FeO} \\
\mathrm{wt} \%[\mathrm{~mol} \%]\end{array}$ & $\begin{array}{l}\mathrm{Al}_{2} \mathrm{O}_{3} \\
\mathrm{wt} \%[\mathrm{~mol} \%]\end{array}$ & $\begin{array}{l}\mathrm{SiO}_{2} \\
\mathrm{wt} \%[\mathrm{~mol} \%]\end{array}$ & $\begin{array}{l}\mathrm{MgO} \\
\mathrm{wt} \%[\mathrm{~mol} \%]\end{array}$ & $\begin{array}{l}\mathrm{Cr}_{2} \mathrm{O}_{3} \\
\mathrm{wt} \%[\mathrm{~mol} \%]\end{array}$ & $\begin{array}{l}\mathrm{MnO} \\
\mathrm{wt} \%[\mathrm{~mol} \%]\end{array}$ \\
\hline 1 & Hercynite & 31.8 [37.9] & $52.1[43.8]$ & - & $4.9[10.4]$ & $8.7[4.9]$ & $2.5[3.0]$ \\
\hline 2 & Fayalite & $62.3[58.3]$ & $1.3[0.9]$ & $30.4[33.6]$ & $1.2[2.0]$ & - & $4.7[4.5]$ \\
\hline 3 & $\mathrm{FeO}_{\mathrm{n}}-\mathrm{Al}_{2} \mathrm{O}_{3}-\mathrm{SiO}_{2}$ liquid slag & $31.3[29.9]$ & $18.1[12.2]$ & $45.7[52.2]$ & $1.2[2.0]$ & - & $3.7[3.6]$ \\
\hline 4 & Hercynite & $33.8[40.3]$ & $59.6[50.0]$ & - & $3.2[6.7]$ & $1.7[1.0]$ & $1.7[2.1]$ \\
\hline
\end{tabular}

(a) Test 3, $\underline{\mathrm{O}}=92 \mathrm{ppm}$

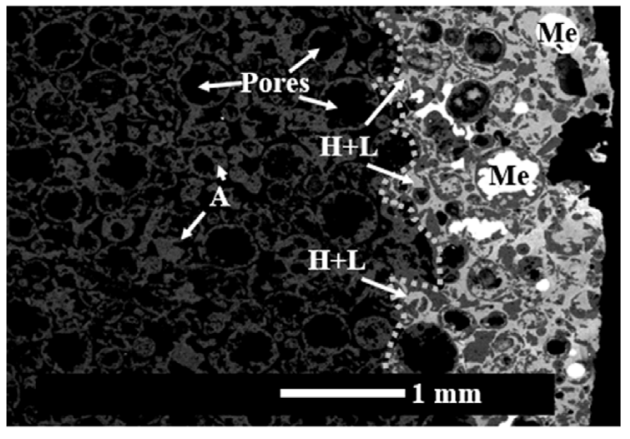

(b) Test $5, \underline{\mathrm{O}}=2.5 \mathrm{ppm}$

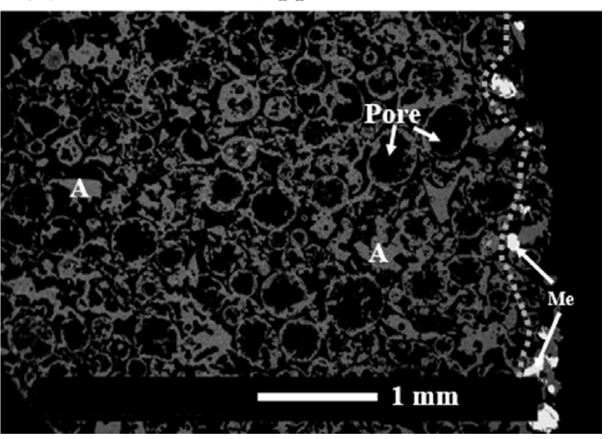

Fig. 8. Changes in the amount and depth of steel infiltration at the hot face of the samples from (a) Test $3, \underline{\mathrm{O}}=92 \mathrm{ppm}$; and (b) Test $5, \underline{\mathrm{O}}=2.5 \mathrm{ppm}$, showing the influence of oxygen level on the steel infiltration: $\mathrm{Me}=$ metallic $\quad$ iron $\quad$ particle; $\mathrm{A}=\mathrm{Al}_{2} \mathrm{O}_{3}$; $\mathrm{H}+\mathrm{L}=\mathrm{FeAl}_{2} \mathrm{O}_{4}$ hercynite $+\mathrm{FeO}_{\mathrm{n}}-\mathrm{Al}_{2} \mathrm{O}_{3}-\mathrm{SiO}_{2}$ liquid slag. Dash line in the figure shows the infiltration limit of molten steel. densified porous alumina plugs are caused by the infiltration of steel into the plug and by the steel/ $\mathrm{Al}_{2} \mathrm{O}_{3}$ plug interactions to form liquid $\mathrm{FeO}_{\mathrm{n}}-\mathrm{Al}_{2} \mathrm{O}_{3}-\mathrm{SiO}_{2}$ slag, $\mathrm{FeAl}_{2} \mathrm{O}_{4}$ hercynite and fayalite in the plug. As shown in Fig. 7, the infiltrating steel and the newly formed phases filled the porous structure of the alumina plug, thereby blocking the path for the carrier gas recirculation (Fig. 4).

\subsubsection{Infiltration of molten steel in porous alumina plugs}

The presence of oxygen in molten steel and oxygen from the carrier nitrogen gas and porosities in plugs bring about a shift from non-wetting to wetting behavior in the iron/alumina system. The contact angle between molten steel and $\mathrm{Al}_{2} \mathrm{O}_{3}$ decreases with increasing oxygen contents in the steel [8-12]. For instance, the measured contact angles between liquid iron and $\mathrm{Al}_{2} \mathrm{O}_{3}$ are $132^{\circ}, 71^{\circ}$ and $68^{\circ}$ corresponding oxygen partial pressures of $1 \times 10^{-14}, 9.9 \times 10^{-4}$ and $3.0 \times 10^{-3}$, respectively [8]. Considering that the same quality of carrier nitrogen gas and porous $\mathrm{Al}_{2} \mathrm{O}_{3}$ plug were used in the probe measurements, oxygen supplied from the carrier gas and plugs in different tests should be also the same. Therefore, it can be concluded that the infiltration of molten steel in the alumina plugs is favored by a high oxygen level in the steel (Fig. 8a), whereas the infiltration of steel into the alumina plug was limited in the steel with a low oxygen content (Fig. 8b).

\subsubsection{Interaction mechanisms between infiltrating iron and alumina plugs}

Note in Figs. 6 and 7 that a large amount of $\mathrm{FeO}_{\mathrm{n}}-\mathrm{Al}_{2} \mathrm{O}_{3}-\mathrm{SiO}_{2}$ slag, $\mathrm{FeAl}_{2} \mathrm{O}_{4}$ hercynite and $\mathrm{Fe}_{2} \mathrm{SiO}_{4}$ fayalite are observed when the alumina plug was infiltrated by molten steel, whereas a low level of FeO-bearing phases is found in the plug contacting with molten steel having a low oxygen level (Fig. 8b). Phase diagram analyses of the $\mathrm{FeO}_{\mathrm{n}}-\mathrm{Al}_{2} \mathrm{O}_{3}-\mathrm{SiO}_{2}$ ternary system (Fig. 9) illustrate that liquid $\mathrm{FeO}_{\mathrm{n}}-\mathrm{Al}_{2} \mathrm{O}_{3}-\mathrm{SiO}_{2}$ slag and $\mathrm{FeAl}_{2} \mathrm{O}_{4}$ hercynite are stable phases at the testing temperatures $\left(\sim 1600{ }^{\circ} \mathrm{C}\right)$ from the steel/plug interactions. $\mathrm{Al}_{2} \mathrm{O}_{3}$ and $\mathrm{SiO}_{2}$ in the slag are mainly from the alumina plug, and $\mathrm{FeO}$ was formed by the oxidation of liquid steel. $\mathrm{FeAl}_{2} \mathrm{O}_{4}$ hercynite precipitates from the slag/plug interactions once the slag is (locally) saturated with $\mathrm{Al}_{2} \mathrm{O}_{3}$. The observed $\mathrm{Fe}_{2} \mathrm{SiO}_{4}$ fayalite should precipitate during quenching of the plug after testing.

Thermodynamic calculations, as shown in Fig. 10, illustrate that $\mathrm{FeO}_{\mathrm{n}}-\mathrm{Al}_{2} \mathrm{O}_{3}-\mathrm{SiO}_{2}$ slag is generated by adding two grams of mullite $\left(3 \mathrm{Al}_{2} \mathrm{O}_{3} \cdot 2 \mathrm{SiO}_{2}\right)$ into the steel at $1600{ }^{\circ} \mathrm{C}$, whereas no slag is generated with the addition of $\mathrm{Al}_{2} \mathrm{O}_{3}$. As shown in Fig. 10a, the increase of oxygen content from $0 \mathrm{ppm}$ to $700 \mathrm{ppm}$ in the steel only slightly increases the amount of the slag (from $1.368 \mathrm{~g}$ to $1.372 \mathrm{~g}$ ) with the addition of two grams of $\mathrm{SiO}_{2}-\mathrm{Al}_{2} \mathrm{O}_{3}$ mixture. These results imply that $\mathrm{FeO}$ is mainly formed through the redox-reactions between steel $(\mathrm{Fe})$ and $\mathrm{SiO}_{2}$ from $\mathrm{SiO}_{2}$-containing phases in the plug. Such oxidation of $\mathrm{Fe}$ by $\mathrm{SiO}_{2}$ from $\mathrm{SiO}_{2}$-containg refractories or mold flux has been also reported $[19,20]$. Note in Fig. 10a that compared with the addition of two grams of mullite, a greater amount of slag is generated when one or two grams $\mathrm{SiO}_{2}-\mathrm{Al}_{2} \mathrm{O}_{3}$ mixture is/are added into the steel because of the enhanced oxidation of molten steel, indicating that the presence of $\mathrm{SiO}_{2}$-rich phases in the porous plug favors the generation of $\mathrm{FeO}_{\mathrm{n}}-\mathrm{Al}_{2} \mathrm{O}_{3}-\mathrm{SiO}_{2}$ slag. Additionally, oxygen from the carrier nitrogen gas, and air and/or moisture in the porosities of the porous alumina plug, can also promote the oxidation of molten steel and facilitates the slag formation. Along with the molten steel, this liquid slag also infiltrated into the porous alumina plug, along the open pore network and grain boundaries (Figs. 6 and 7). Since the increased oxygen content in the molten steel favors the infiltration of steel into the porous alumina plug, more $\mathrm{SiO}_{2}-$ containing phases inside the plug could contact with molten steel. As a result, larger amounts of $\mathrm{FeO}_{\mathrm{n}}-\mathrm{Al}_{2} \mathrm{O}_{3}-\mathrm{SiO}_{2}$ slag are generated in the plug contacting with molten steel having higher oxygen levels. In comparison, a small amount of steel infiltrated into the porous alumina plug in the molten steel with a low oxygen content ( $2.5 \mathrm{ppm}$, Fig. $8 \mathrm{~b})$. As a result, the formation of $\mathrm{FeO}_{\mathrm{n}}-\mathrm{Al}_{2} \mathrm{O}_{3}-\mathrm{SiO}_{2}$ liquidus slag is suppressed. Additionally, the increased $\mathrm{Si}$ content in molten steel, due to the addition of Fe-Si alloy, also hinders the generation of liquidus slag by suppressing the redox-reactions between steel (Fe) and $\mathrm{SiO}_{2}$ (Fig. 10).

To describe plug components dissolution, and plug/steel (or slag) interactions during testing and precipitates formation during quenching in local regions at plug/steel (or slag) interface in the plug, the phase diagram of $\mathrm{FeO}_{\mathrm{n}}-\mathrm{Al}_{2} \mathrm{O}_{3}-\mathrm{SiO}_{2}$ ternary system, representing the equilibrium state, can be used. As shown in Fig. 9, the initially formed $\mathrm{FeO}_{\mathrm{n}^{-}}$ $\mathrm{Al}_{2} \mathrm{O}_{3}-\mathrm{SiO}_{2}$ slag is completely undersaturated in both $\mathrm{Al}_{2} \mathrm{O}_{3}$ and $\mathrm{SiO}_{2}$, as a result $\mathrm{Al}_{2} \mathrm{O}_{3}$ and $\mathrm{SiO}_{2}$-containing phases in the porous alumina plug inevitably dissolved into the slag. The evolution of the slag composition during the dissolution of plug components follows an idealized path from point " $a$ " with a high $\mathrm{FeO}_{\mathrm{n}}$ content to point " $b$ " (or point " $b$ ") and then to point " $c$ " as described in Fig. 9, depending on the dissolution rates and amounts of $\mathrm{Al}_{2} \mathrm{O}_{3}$ and $\mathrm{SiO}_{2}$-containing phases into the slag. Besides the dissolution of $\mathrm{Al}_{2} \mathrm{O}_{3}$ and $\mathrm{SiO}_{2}, \mathrm{CaO}$ and $\mathrm{Na}_{2} \mathrm{O}$ in the plug can also dissolve into the liquid $\mathrm{FeO}_{\mathrm{n}}-\mathrm{Al}_{2} \mathrm{O}_{3}-\mathrm{SiO}_{2}$ slag. Additionally, other 


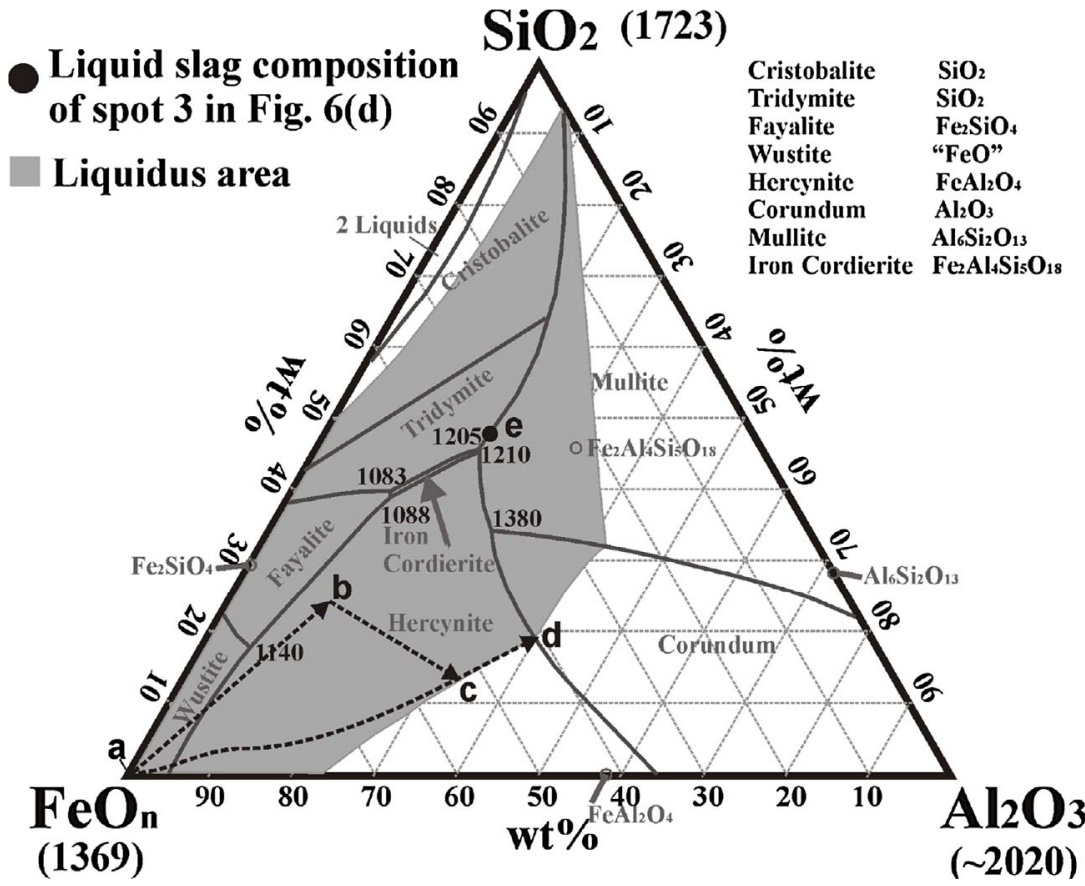

Fig. 9. Liquidus projection at $1600{ }^{\circ} \mathrm{C}$ in the $\mathrm{Al}_{2} \mathrm{O}_{3}-\mathrm{FeO}_{\mathrm{n}}-\mathrm{SiO}_{2}$ in contact with metallic iron after Schairer [16] and Galakhov [17], as drawn by Muan and Osbon [18]. steel components, e.g. Mn, could also be oxidized into $\mathrm{MnO}$ [21] and enter into the liquid slag. The presence of these oxides, e.g. $\mathrm{CaO}, \mathrm{Na}_{2} \mathrm{O}$ and $\mathrm{MnO}$, in the slag could further decrease the slag melting temperature and thus favor the $\mathrm{Al}_{2} \mathrm{O}_{3}$ and $\mathrm{SiO}_{2}$ dissolution, thereby increasing the amount of liquid slag. When slag composition reaches point " $c$ ", the slag will be saturated with $\mathrm{FeAl}_{2} \mathrm{O}_{4}$ hercynite. The $\mathrm{FeAl}_{2} \mathrm{O}_{4}$ hercynite, therefore, precipitated from the slag at the slag/ $\mathrm{Al}_{2} \mathrm{O}_{3}$ interface (Fig. 7a) according to Eq. (1).

$\mathrm{Al}_{2} \mathrm{O}_{3, \text { slag }}+\mathrm{FeO}_{\text {slag }}=\mathrm{FeAl}_{2} \mathrm{O}_{4, \text { solid }}$

Oxides, e.g. $\mathrm{MgO}, \mathrm{MnO}$ and $\mathrm{Cr}_{2} \mathrm{O}_{3}$ originating from refractory dissolution or from steel oxidation, in the slag would be incorporated in the herynite formation, generating hercynite-based solid solutions (Table 2).

Further generation of $\mathrm{FeO}_{\mathrm{n}}$ at the steel/plug interfaces and dissolution of $\mathrm{Al}_{2} \mathrm{O}_{3}$ into the slag could enhance the formation of hercynite along the unreacted $\mathrm{Al}_{2} \mathrm{O}_{3}$ grains [22]. The liquid slag composition, therefore, changes to point " $d$ " (in Fig. 9). When the plug was cooled down after the measurement, hercynite would further precipitate from the slag and might exhibit dendritic and angular shaped morphology, as shown in Fig. 7d. Fayalite phase can also precipitate from the $\mathrm{SiO}_{2}$-rich slag with further cooling of the plug, which could be proved by its dendritic and angular shape (Fig. 7b). As the precipitation of hercynite and fayalite would enrich the liquid slag in $\mathrm{SiO}_{2}$, the slag composition changes to point " $e$ " in Fig. 9. This is in good agreement with the chemical composition at spot 3 (Table 2).

\subsubsection{Densification scheme of porous alumina plugs}

Based on the microstructural and chemical analyses of the recovered alumina plugs, a scheme of the densified porous alumina plug in molten steel with oxygen contamination is proposed in Fig. 11. The infiltration of high oxygen content molten steel and formation of $\mathrm{FeO}_{\mathrm{n}}-\mathrm{Al}_{2} \mathrm{O}_{3}-\mathrm{SiO}_{2}$ slag due to redox-reactions between steel $(\mathrm{Fe})$ and $\mathrm{SiO}_{2}$ from $\mathrm{SiO}_{2}$ containing phases in the plug are primarily responsible for the densification of the plug. The high oxygen level in the steel favors the steel infiltration by improving the wetting of $\mathrm{Fe}$ on $\mathrm{Al}_{2} \mathrm{O}_{3}$. As a result more $\mathrm{SiO}_{2}$-containing phases interact with molten steel, generating larger amounts of $\mathrm{FeO}_{\mathrm{n}}-\mathrm{Al}_{2} \mathrm{O}_{3}-\mathrm{SiO}_{2}$ slag inside the porous alumina plug (Fig. 11a). The newly-formed liquid $\mathrm{FeO}_{\mathrm{n}}-\mathrm{Al}_{2} \mathrm{O}_{3}-\mathrm{SiO}_{2}$ slag and the infiltrating molten steel fill the open pore network of the plug (Fig. 11b). $\mathrm{FeAl}_{2} \mathrm{O}_{4}$ hercynite is generated from the steel/plug interactions once the slag is (locally) saturated with $\mathrm{Al}_{2} \mathrm{O}_{3}$ (Fig. 11b). As a result, the microstructure at the hot face of the alumina plug changed from the original porous structure with a large open pore network (Fig. 3a) to a dense mixture consisting of infiltrating steel, hercynite, liquid slag and unreacted $\mathrm{Al}_{2} \mathrm{O}_{3}$ particles (Figs. 7 and $11 \mathrm{c}$ ), thereby blocking the carrier gas recirculation. The densification of the porous alumina plug is therefore occurring.

To decrease the densification and thereby to increase the accuracy of the hydrogen measurement, measures can be suggested as (a)

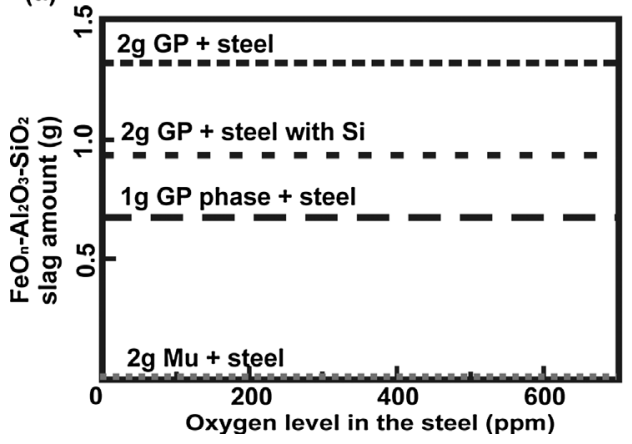

(b)

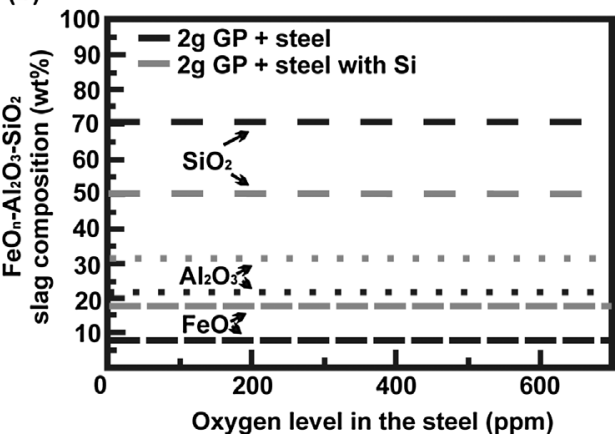

Fig. 10. (a) amounts of $\mathrm{FeO}_{\mathrm{n}}-\mathrm{Al}_{2} \mathrm{O}_{3}-\mathrm{SiO}_{2}$ liquidus slag generated by adding refractory components into molten steel, and (b) slag compositions $\mathrm{FeO}_{\mathrm{n}}-\mathrm{Al}_{2} \mathrm{O}_{3}$ $\mathrm{SiO}_{2}$ liquidus slag generated in molten steel without or with $0.47 \mathrm{wt} \% \mathrm{Si}$, as predicted by thermodynamic calculations at $1600{ }^{\circ} \mathrm{C}$ : $\mathrm{GP}, \mathrm{SiO}_{2}-\mathrm{Al}_{2} \mathrm{O}_{3}$ mixture, $\mathrm{Mu}$, mullite. 


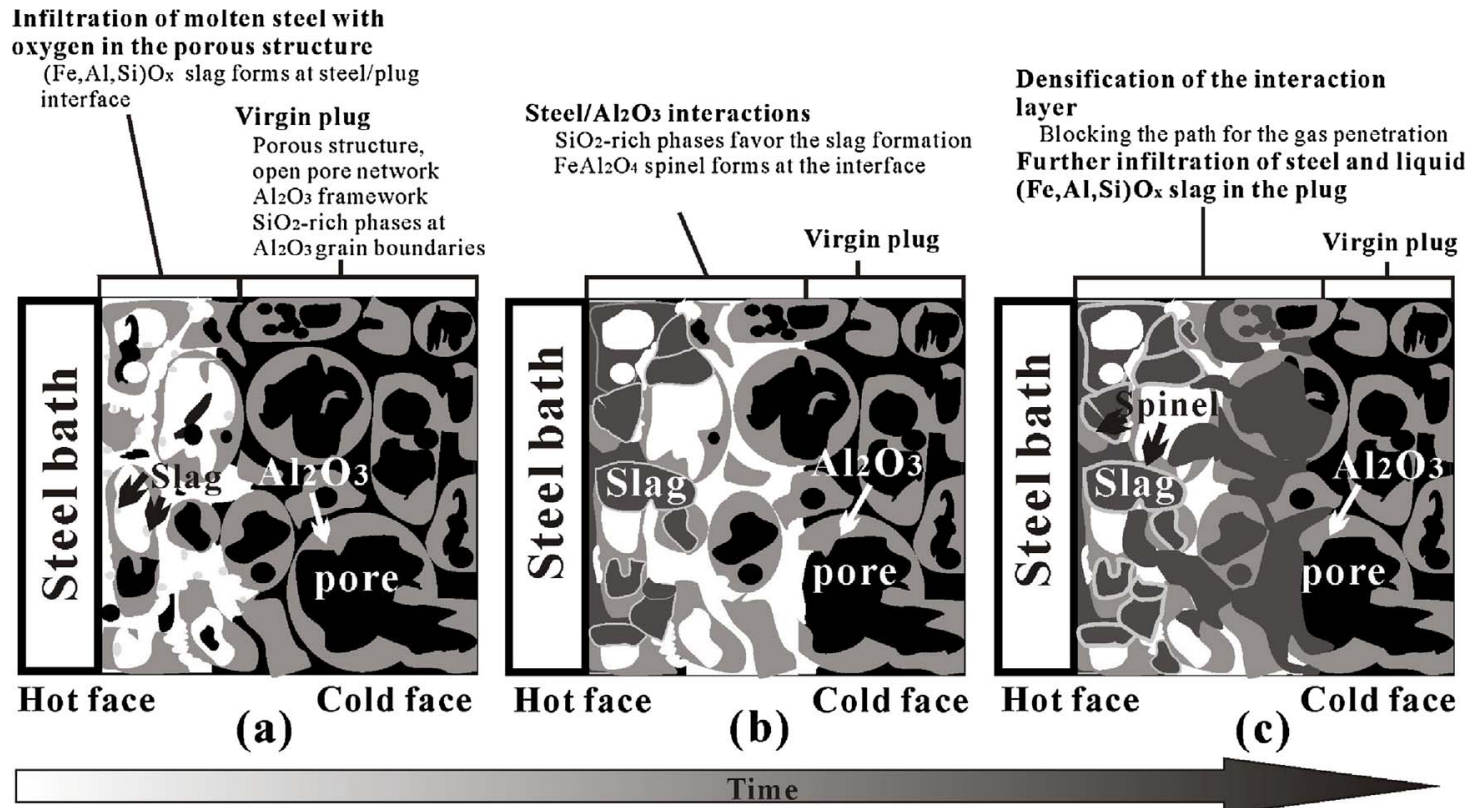

Fig. 11. Schematic representation of the densification of porous alumina plug in molten steel.

followings: (1) preventing iron infiltration into the plug, by reducing the dimension of the open pores or by using other plug materials, which are less wetted by iron with a high oxygen level; and (2) mitigating liquid slag formation in the interaction layer by reducing or avoiding the $\mathrm{SiO}_{2}$ in the plug.

\section{Conclusions}

The densifying behavior of the porous alumina plug was investigated by hydrogen measurement (Hydris probe system) tests. These tests were performed in an induction furnace filled with steel with distinct oxygen levels of the molten steel controlled by Fe-Si alloy and $\mathrm{Al}$ killing. Based on macroscopical observations and microstructural characterization of the recovered alumina plug, the following conclusions can be drawn:

(1) The densifying behavior of the alumina plug was significantly affected by the oxygen content in molten steel, as demonstrated by the measured curves of the hydrogen content and carrier gas pressure, and by the appearance of the plug after measurements. The higher the oxygen level in the steel, the more severe densification of the alumina plug is.

(2) $\mathrm{FeO}_{\mathrm{n}}-\mathrm{Al}_{2} \mathrm{O}_{3}-\mathrm{SiO}_{2}$ liquidus slag was generated due to the redox-reactions between steel $(\mathrm{Fe})$ and $\mathrm{SiO}_{2}$ from $\mathrm{SiO}_{2}$-containing phases in the plug.

(3) Oxygen containing steel infiltrated into the porous alumina plug, because oxygen can favor the wetting of iron on $\mathrm{Al}_{2} \mathrm{O}_{3}$. The enhanced molten steel infiltration favors the generation of $\mathrm{FeO}_{\mathrm{n}}$ $\mathrm{Al}_{2} \mathrm{O}_{3}-\mathrm{SiO}_{2}$ liquidus slag. $\mathrm{FeAl}_{2} \mathrm{O}_{4}$-based hercynite precipitated along unreacted $\mathrm{Al}_{2} \mathrm{O}_{3}$ phase from the slag once the slag is (locally) saturated with $\mathrm{Al}_{2} \mathrm{O}_{3}$. The infiltrating steel, the newly-formed slag and hercynite fill the open pore network of the plug, thereby blocking the path for the carrier gas recirculation and thus densifying alumina plugs. Therefore, the densification of alumina plug occurs in molten steel with high oxygen levels.

(4) $\mathrm{High} \mathrm{SiO}_{2}$ content phases in the plug facilitate the formation of liquid $\mathrm{FeO}_{\mathrm{n}}-\mathrm{Al}_{2} \mathrm{O}_{3}-\mathrm{SiO}_{2}$ slag, favoring the densification of alumina plug.

(5) The densification of porous alumina plug was limited by lowering the oxygen level in molten iron. This is because the infiltration of steel was hindered and the formation of $\mathrm{FeO}_{\mathrm{n}}-\mathrm{Al}_{2} \mathrm{O}_{3}-\mathrm{SiO}_{2}$ slag was inhibited.

\section{Acknowledgements}

The authors are grateful to the engineers of Electro-Nite for their close co-operation.

\section{References}

[1] R.P. Stone, E.T. Turkdogan, D. Vensel, Experimental determination of the accuracy of hydrogen measurement in liquid steel with hydris system, Proceeding of $74^{\text {th }}$ Steel Making Conference, Washington DC, 1991, pp. 22-24.

[2] G. Frigm, R.P. Stone, J. Plessers, R.S. Bogan, E.T. Turkdogan, Accuracy Hydrogen Measurement Liquid Steel With In-Situ Microprocessor-Based System, (1991).

[3] W. Glitscher. 15 Years HYDRIS - a Revolutionary Method to Control Hydrogen Has Become Mature. 1-8 (https://www.heraeus.com/media/media/hen/media_hen/ products_hen/steel/pdfs_steel/15_years_hydris.pdf).

[4] S. Ali, R. Mutharasan, D. Apelian, Physical refining of steel melts by filtration, Metall. Trans. B 16 (4) (1985) 725-742.

[5] C.G. Aneziris, S. Dudczig, M. Emmel, H. Berek, G. Schmidt, J. Hubalkova, Reactive filters for steel melt filtration, Adv. Eng. Mater. 15 (1-2) (2013) 46-59.

[6] X.H. Ren, P. Zhao, Q.H. Lai, X. Qin, Analysis to mullite bonded corundum purging plug, In Appl. Mech. Mater. 423-426 (2013) 49-52.

[7] Z. Lan, S. Tian, H. Chen, Effects of corundum granularities on properties of $\mathrm{Al}_{2} \mathrm{O}_{3}$ ZrB 2 porous plug, Refractories (Chin.) 43 (1) (2009) 48-50.

[8] E. Kapilashrami, A. Jakobsson, S. Seetharaman, A.K. Lahiri, Studies of the wetting characteristics of liquid iron on dense alumina by the X-ray sessile drop technique, Metall. Mater. Trans. B 34 (2) (2003) 193-199.

[9] K. Nogi, K. Ogino, Role of interfacial phenomena in deoxidation process of molten iron, Can. Metall. Q. 22 (1) (1983) 19-28.

[10] M. Humenik, W.D. Kingery, Metal-ceramic interactions: III, surface tension and wettability of metal-ceramic systems, J. Am. Ceram. Soc. 37 (1954) 18-23.

[11] A. Kasama, A. McLean, W.A. Miller, Z. Morita, M.J. Ward, Surface tension of liquid iron and iron-oxygen alloys, Can. Metall. Q. 22 (1) (1983) 9-17.

[12] I. Jimbo, A.W. Cramb, Computer aided interfacial measurements, ISIJ Int. 32 (1) (1992) 26-35.

[13] C.W. Bale, E. Bélisle, P. Chartrand, S.A. Decterov, G. Eriksson, A.E. Gheribi, K. Hack, I.-H. Jung, Y.-B. Kang, J. Melançon, A.D. Pelton, S. Petersen, C. Robelin, J. Sangster, P. Spencer, M.-A. Van Ende, FactSage thermochemical software and databases, 2010-2016, Calphad 54 (2016) 35-53.

[14] D.P. Dutta, G. Sharma, Synthesis and magnetic behavior of spinel $\mathrm{FeAl}_{2} \mathrm{O}_{4}$ nanoparticles, Mater. Sci. Eng., B 176 (2) (2011) 177-180.

[15] J. Chen, L. Yu, J. Sun, Y. Li, W. Xue, Synthesis of hercynite by reaction sintering, J. Eur. Ceram. Soc. 31 (3) (2011) 259-263.

[16] J.F. Schairer, Kenzo Yagi, The system $\mathrm{FeO}-\mathrm{Al}_{2} \mathrm{O}_{3}-\mathrm{SiO}_{2}$, Am. J. Sci. (1952) 471-512.

[17] F.Y. Galakhov, $\mathrm{Al}_{2} \mathrm{O}_{3}$ region of ternary aluminosilicate systems I: the $\mathrm{FeO}-\mathrm{Al}_{2} \mathrm{O}_{3}$ $\mathrm{SiO}_{2}$ and $\mathrm{MnO}-\mathrm{Al}_{2} \mathrm{O}_{3}-\mathrm{SiO}_{2}$ systems, Izvest. Akad. Nauk SSSR. Otdel. Khim. Nauk (1957) 525-531.

[18] A. Muan, E.F. Osborn, Phase Equilibria Among Oxides in Steelmaking, AddisonWesley Pub. Co., 1965. 
[19] P. Yan, M.A. Van Ende, E. Zinngrebe, S. van der Laan, B. Blanpain, M. Guo, Interaction between steel and distinct gunning materials in the tundish, ISIJ Int. 54 (11) (2014) 2551-2558.

[20] M.-S. Kim, S.-W. Lee, J.-W. Cho, M.-S. Park, H.-G. Lee, Y.-B. Kang, A reaction between high $\mathrm{Mn}$-high $\mathrm{Al}$ steel and $\mathrm{CaO}-\mathrm{SiO}_{2}$ type molten mold flux: part I. composition evolution in molten mold flux, Metall. Trans. B 44 (4) (2013) 299-308.
[21] L. Chen, A. Malfliet, P.T. Jones, B. Blanpain, M. Guo, Degradation mechanisms of alumina-silica runner refractories by carbon steel during ingot casting process, Ceram. Int. 42 (8) (2016) 10209-10214.

[22] S. Zhang, W.E. Lee, Use of phase diagrams in studies of refractories corrosion, Int. Mater. Rev. 45 (2) (2000) 41-58. 